\title{
Study on the Co-education Pattern of Colleges and Enterprises
}

\author{
Xiuzhen Li \\ Department of Radiology \\ Taishan Medical University \\ Taian City, China \\ zhenlixiu@163.com
}

\author{
Deyun Yang \\ Department of Information Science and Technology \\ Taishan University \\ Taian City, China \\ yangdeyun163@163.com
}

\begin{abstract}
In recent years, there are some problems in training of talents in the application-oriented undergraduate colleges in China. First we analyze the current situation of students training in applied colleges, then prefer to have a comprehensive understanding of the enterprises and students' status. Finally we suggest a overall education plan and a training process based on the college-enterprise cooperation.
\end{abstract}

Keywords-College-enterprise Cooperation; Application-oriented Colleges; Talents training; Cultivate talents, Employment.

\section{CURRENT SITUATION OF STUDENTS TRAINING IN APPLIED COLLEGES IN CHINA}

In recent years, local colleges have become important parts of undergraduate training in China. However, there are some problems in training of talents in the application-oriented undergraduate colleges.

\section{A. The positioning of application-oriented colleges is not determined}

Although the positioning of newly-established colleges is application-oriented, the colleges is in fact still in the direction of academic research university, such as the present teaching and scientific research system, the introduction and cultivation of college teachers, the teacher evaluation system and job classification system, etc. The reason of the above cases is that it is generally accepted that the applied colleges is low in grade, and not perfect in management. The shaky orientation of the colleges leads to the unclear orientation of their majors.

\section{B. The teaching system is out of step with industry demands}

China is a big country with potential human resources. Therefore, the enterprises are in an absolute position in employment relations, which leads to the lack of awareness of personnel training in China's enterprises. And the teaching system of colleges is not perfect, ignoring the role of industrial development in promoting advanced technology and renewing knowledge and having weak awareness of practical teaching. The knowledge and quality education are mostly in the teaching methods, so that the integration of theoretical teaching and engineering practice is not enough, which leads to the lack of practical ability of professional post for the new graduates. Therefore most of the graduates have a longer period of adaptation. At the same time, the college graduates' frequent job hopping has become a good anxiety of the employers, which is what Chinese companies are unwilling to see. So "ready for use" has been the basic requirement for most of enterprises to employ college graduates.

For the above reasons, it is necessary to study co-education patterns of colleges and enterprises. Career goals and life goals are the most important goal orientations of college students. Based on co-education patterns of colleges and enterprises, by allowing students to understand the industry, familiar with the enterprises, timely and targeted occupation planning education for students, we should make students form clear employment goals and career planning, which can effectively solve the blind spot in the struggle goal of college students and stimulate the students' learning motivation.

\section{HAVE A COMPREHENSIVE UNDERSTANDING OF THE ENTERPRISES AND STUDENTS' STATUS}

In the following we take computer major as an example. The talents training of computer majors in colleges is oriented to information technology research and services, and the main channel of employment is IT enterprises. Therefore it is essential to have a comprehensive understanding of the enterprises and students' status with a career objective. Here we suggest to build a IT enterprises' information database, which includes the following aspects.

\section{A. Hierarchy of IT Enterprises}

Computer hardware: storage, processing, transmission equipments; Software: the storage, retrieval and analysis of network data; using data analysis model to assist decision making.

\section{B. Classification of IT Enterprises}

Hardware: system integration enterprises; Outsourcing enterprise: software development enterprises; Trade category: Ecommerce enterprises; Multi services: Internet business. 


\section{Classify jobs}

For example, in a software enterprise, the posts and proportion of their employees are as follows.

Software R \& D personnel (R \& D ground , R \& D work) 55\%; Software implementers (customer site deployment and maintenance) 25\%; Software testers (internal and external monitoring) 5\%; Featured personnel (DBA/ artist / Architect) 5\%; Operation personnel (website / platform / pre-sales / customer service) $10 \%$.

\section{Analyze talent demand for different positions}

For example, in a software enterprise, the requirements for R \& D engineers (creating value for the enterprise) are as follows.

The basic programming language, such as C/JAVA/.NET; Ability to master basic database / data structure; Extensibility: framework / tools / containers; Model transformation capability: business to code.

Similarly, there are corresponding requirements for implementation engineer (to achieve value for the enterprise), test engineers (to improve value for enterprises), and technical personnel (escort for enterprises), etc.

\section{E. Methods of employment assessment}

The entry requirements and admissions process are as follows.

Basic skills (work language / work tool use); Work habits (programming habits / work hours / work specifications); Model conversion rate (ability of converting business to code); Team work ability (team project); Advanced technical skills; Basic business knowledge, etc.

College life is a key phrase in a student's growth, and the first year at college is the most crucial period. Through a powerful study of enterprises, leading students to understand the industry, enterprises and jobs, the students have been given individual guidance to form clear career goals and career development planning. Then we make the students "confident in learning, confident in employment and confident in success." Therefore, it is necessary to build up the archives for students' growth, which mainly record each stage of the students' progress.

\section{A VARIETY OF CO-EDUCATION PATTERNS OF COLLEGES AND ENTERPRISES ARE ANALYZED}

There are some effective patterns of college-enterprise cooperation in foreign countries, some mainly in enterprises, some in schools, and some in industry. Their common point is that they have complete vocational education laws and regulations. The enterprises participate in the whole process of running colleges. They have the active support of the government's fiscal and policy, and establish a complete social security system. In our country, we should explore effective modes of college-enterprise cooperation on the basis of the national conditions, the present situation of enterprises and the characteristics of colleges and specialties. Therefore we suggest to analyze and compare the characteristics of the existing models of college- enterprise cooperation, and construct the mode of "imparting knowledge to educate people \& practice to cultivate talents" based on college-enterprise cooperation. Some typical cases of college-enterprise cooperation are as follows:

College-enterprise cooperation in computer-related majors in some university, such as Beijing Jiaotong University or Hefei university, etc.

College-enterprise co-education pattern involving IT enterprises or IT training institutions, such as Beijing tarena, Chinasoft International ( Beijing), Ambow Education Holding Ltd, Huawei, ZTE, Zhongke Shuguang, etc.

Taking students as the center, according to the training target and the colleges' positioning, as well as the social demand which the students should achieve, we should focus on the raise of "the knowledge, the ability, the quality" so as to highlight the applied characteristics. In order to develop deep cooperation characteristics of talent training scheme, we must study three major curriculum systems-theory, practice and quality of occupation, to build a stable and dynamic coordinated curriculum group with the form "a platform \& multi-modules". Moreover, to refine the task of college-enterprise cooperation and the quality standard of the course and to construct an effective practice teaching system are the keys to the training of applied talents.

The overall education plan of "imparting knowledge to educate people \& practice to cultivate talents" based on collegeenterprise cooperation is as follows:

- laying groundwork \& making plan in the first year.

- Thickening foundation \& melting technology in the second year.

- Finning direction \& embedding project in the third year.

- Improving quality \& strengthening ability in the last year.

During the whole period of college, colleges mainly carry out the study of knowledge and cultural quality, while enterprises mainly implement career planning, professional quality and engineering techniques. In this mode of cooperation between colleges and enterprises, enterprises can educate students through the whole process and create an enterprise working 
environment and professional environment for training students, which tries to cultivate high-level and applied talents, and makes the colleges to be integrated and innovative education bases.

In the implementation of the personnel training program, we should make a scientific training process.

- Target: college personnel training objectives and standards, and students' career development expectations.

- Process mainline: For students' growth, construction of the mechanism on knowledge learning, transformation and application, which is the vein of the whole talent training mechanism and leads to the gradient development of students' quality and ability, realizes the unity of teaching and practice training.

- Process sub line: Focus on managers or teachers.

- Process design: The process design should be carried out from the aspects of colleges, specialties and courses.

- Node-based control: Find out the key nodes of students' ability development and talent training quality, and establish the mechanism of inspection, evaluation, feedback and improvement. This is the key to ensure the quality of personnel training and promote the ability of students.

- Spatial interlinking: The main and sub line processes and related resources shall be scientifically organized and prepared to promote the optimization of the spatial layout of talents training, the promotion of practical efficiency and the coordination of teaching rhythm.

- Establish an incentive and communication mechanism between colleges and enterprises.

\section{SUMMARY}

The core of talent training is the self-development and self-discipline mechanism of students. However, under the popularization of education, the educational foundation of the new local undergraduate students has been greatly reduced in China, which causes the students' self-management ability to be weak. The co-education pattern of colleges and enterprises has achieved the combination of professional curriculum learning and professional accomplishment through the dual tutorial system. This strengthens the degree of love for students, leads students to self-education, leads the educational process, and gradually develops and constrains themselves. This lays the foundation for the students to grow up and become a useful person.

The college-enterprise cooperation education not only displays in the specialized knowledge and the skill, moreover manifests in the personality and the synthesis accomplishment education. The education of students is not only in the classroom teaching, but also should pay attention to the enterprise culture education, practice education, discipline education and so on. From the professional quality, we should pay attention to training three habits: punctuality, sureness and diligence, to cultivating three abilities adaptability, learning ability, compressive ability, to set up three consciousness: standard consciousness, cooperation consciousness and communication consciousness. In addition, in view of software infringement and cyber crime, the moral quality education for students majoring in computer science is to highlight the view of world, life, worth and even laws.

\section{REFERENCES}

[1] Yunjie Tu, Yang Bai, On the Reform of practical teaching in computer majors based on the application-oriented talents training target, Journal of Hulunbeier University,2016, pp. 107-109.

[2] Ting Yu, Jianhua Wang, Study on College-Enterprise Cooperation in Practical Teaching of Computer Majors, Computer Education, 2009 , pp. 47-49.

[3] Lina He, Strategies of Integrating Corporate Culture into Higher Vocational Colleges under the Mode of School-Enterprise Cooperation, Journal of Kaifeng Institute of Education, 2014, pp. 181-183.

[4] Peiming Fu, On the integration of campus culture and corporate culture under the mode of school-enterprise cooperation, Chinese Vocational and Technical Education, 2011, pp. 26-28. 